\title{
Urbanization, Environment and Homelessness in the Developing world: The Sustainable Housing Development.
}

\author{
Akinluyi, Muyiwa Lawrence \\ B.Sc. Ife. M. Arch. Ife. \\ Department of Architecture Joseph Ayo Babalola University (JABU), \\ Ikeji-Arakeji,P.M.B 5006, Osun-State, Nigeria. \\ E-mail:Muyee_007@yahoo.com Phone No: 08032078215 \\ Adedokun, Adeniyi \\ Associate Professor \\ Department of Architecture Joseph Ayo Babalola University (JABU), \\ Ikeji-Arakeji,P.M.B 5006, Osun-State, Nigeria.
}

\section{Doi:10.5901/mjss.2014.v5n2p261}

\begin{abstract}
The problem of homelessness has been necessitated by several factors, including persistent population increases, inadequate housing, and uncontrolled urban growth pattern resulting in "homelessness" among the vast majority of urban dwellers. The need to ensure decent and affordable shelter to the people, particularly the urban poor, is therefore central to the achievement and improvement of both human living standards and societal development (Jiboye, 2011). This paper examined the relevant discussion on Urbanization, Environment and Homelessness in the developing world. Empirically, it determined the numbers of homeless people, Solutions effects and causes of homelessness on people of Ibadan as the challenges of inadequate housing to sustainable housing development in Nigeria. However, it is necessary to have the wider understanding of the homelessness phenomenon as the problem of housing shortage in the developing world. This study was carried out through a survey method using an instrument called questionnaire which was administered to the homeless people in Ibadan. The result of the study justified the need for urgent attention from government and other stakeholders towards addressing the problems of homelessness and inadequate housing among the urban poor and those that are deprived access to decent shelters in the developing world.
\end{abstract}

Keywords: urbanization, Sustainable Housing Environment, homelessness, developing world

\section{Introduction}

Urbanization or urban drift is the physical growth of urban areas as a result of global change. Urbanization is also defined by the United Nations as movement of people from rural to urban areas with population growth equating to urban migration (United Nations, 2008). Urbanization can describe a specific condition at a set time, i.e. the proportion of total population or area in cities or towns, or the term can describe the increase of this proportion over time. The term urbanization can represent the level of urban relative to overall population, or it can represent the rate at which the urban proportion is increasing. Urbanization occurs naturally from individual and corporate efforts to reduce time and expense in commuting and transportation while improving opportunities for jobs, education, housing, and transportation. Living in cities permits individuals and families to take advantage of the opportunities of proximity, diversity, and market place competition. People move into cities to seek economic opportunities. A major contributing factor is known as "rural flight". In rural areas, often on small family farms, it is difficult to improve one's standard of living beyond basic sustenance. Farm living is dependent on unpredictable environmental conditions, and in times of drought, flood or pestilence, survival becomes extremely problematic. In modern times, industrialization of agriculture has negatively affected the economy of small and middle-sized farms and strongly reduced the size of the rural labour market. The housing need has thus been an issue of global concern as the housing provision still remains one of the intractable problems facing mankind (Konadu-Agyemang, Noonam,). The most adversely affected in this regard are the urban poor, who constitute the majority in the developing countries of Africa and Asia wherein, according to a UN Report, consists of cities which now account for over 90 percent of the world's urban population growth (UN -Habitat, 2006). 
In developing countries where there is rapid urbanization, the problem of inadequate housing for the people, especially among the low-income group, constitutes one of the major challenges to economic development and the welfare of citizens. Housing is universally acknowledged as one of the most basic human needs for life and it is a residential structure where man lives and grows (Aluko, 2004; Akinluyi \& Akingbohungbe, 2012) more than 1 billion people one quarter of the world's population live without shelter or in unhealthy and unacceptable conditions and over 100 million people around the world have no shelter whatsoever. The health consequences of this level of homelessness are profound. (Human Development Report, 1997). Existing studies have shown the rate at which urban growth are increasing in most African countries, and the major factors for these rapid increases, relate to large-scale migration into the urban centers for employment and wealth acquisition, natural increase of the population, and lopsided concentration of investments by both governments and private organizations (Ajala, 2005; Jiboye \& Omoniyi, 2010). Despite these rapid growths and population increases, evidence also revealed a rapid decrease in the addition of new housing stock, as well as poor state and inadequate urban housing infrastructures to support the increasing population (Aguda \& Ajala, 1998; Jiboye, 2009). One of the characteristic and consistent human behaviors over thousands of years is that humans build shelters. Homes offer protection from the elements and from a variety of health hazards and provide basic amenities such as a secure place to eat and sleep, to keep one's possessions, to raise a family, and be part of a community.

Homelessness is about a lack of connectedness. It may be describe as the absence or extreme precariousness of housing gives rise to a number of problems that are major factors in the deterioration of the quality of life, such as difficulty in maintaining emotional ties, obtaining services, protecting personal property and securing physical safety. Homelessness also describes the condition of people without a regular dwelling. Everyone has the right to a standard of living adequate for the health and well-being of himself and of his family, including food, clothing, medical care, housing and necessary social services, and the right to security in the event of unemployment, sickness, disability, widowhood, old age or other lack of livelihood in circumstances beyond his control. People who are homeless are unable or unwilling to acquire and maintain regular, safe, and adequate housing, or lack "fixed, regular, and adequate night-time residence. This study will expose our knowledge to the proper definition of homelessness, causes of homelessness, types, characteristics, effects and consequence of homelessness in the developing world.

\section{Conceptual Issues and Related Literature Review}

\subsection{Urbanization and its Environmental effect.}

Urbanization refers to the increase in the proportion of the world's population that lives in "Cities", generally represented by towns, urban area and others spatial forms. Urbanization is not always attributed to high density. Industrialization has frequently been used interchangeably with Urbanization. In some part of the world industrialization and urbanization have gone hand in hand and have developed together. In the process of developing, one may eventually exceed the other. For example, it is possible to have large agglomeration of people at relatively high densities without Industrialization; e.g. large cities in china also in Nigeria some state may also fall into this category in Nigeria e.g. Ekiti State and Osun- State, here there is high level of urbanization; but low level of Industrialization, which implies that, the available Industries are not sufficient for the population available. Also it is possible to have industrialization without a high level of Urbanization. Therefore, the two terms should not be used interchangeably because there is no correlation between them, though they tend to take place at much the same time. With the rapid growth of Third World towns and cities, there have been huge accompanying environmental problems, the growth of subserviced self-help housing on marginal land being only one among them. As this example illustrates, it is often the poorest urban dwellers that bear the brunt of environmental problems; indeed, Hardoy et al. (1992) comment that if one could map such problems in any given city, they would strongly coincide with the poor areas. Yet the problems of simply meeting the basic needs of their urban populations leave many governments in the Third World unable to devote adequate resources to environmental issues. The Earth Summit in Rio de Janeiro (1991) focused global attention on environmental problems, and many of those that are found in Third World cities feature in Agenda 21, one of the Summit's documents. Whether trees have a role in improving Third World urban environments is explored in which the role of trees in providing urban dwellers with material benefits, and thus contributing in another sense to sustainable development, is also discussed. First, however, the present existence of trees, and potential for their increased cultivation, is considered in terms of town/city layout.

The urban heat island has become a growing concern and is increasing over the years. The urban heat island is formed when industrial and urban areas are developed and heat becomes more abundant. In rural areas, a large part of 
the incoming solar energy is used to evaporate water from vegetation and soil. In cities, where less vegetation and exposed soil exists, the majority of the sun's energy is absorbed by urban structures and asphalt. Hence, during warm daylight hours, less evaporative cooling in cities allows surface temperatures to rise higher than in rural areas. Additional city heat is given off by vehicles and factories, as well as by industrial and domestic heating and cooling units. This effect causes the city to become 2 to $10^{\circ} \mathrm{F}\left(1\right.$ to $\left.6^{\circ} \mathrm{C}\right)$ warmer than surrounding landscapes. Impacts also include reducing soil moisture and intensification of carbon dioxide emissions. In his book Whole Earth Discipline, Stewart Brand argues that the effects of urbanization are on the overall positive for the environment. Firstly, the birth rate of new urban dwellers falls immediately to replacement rate, and keeps falling. This can prevent overpopulation in the future. Secondly, it puts a stop to destructive subsistence farming techniques, like slash and burn agriculture. Finally, it minimizes land use by humans, leaving more for nature.

\subsection{Demographic Trends in the Urbanization Process}

In examining the potential of urbanization for improving the well-being of Third World urban dwellers, some appreciation is needed and in what conditions they live. The income levels of urban residents in developing countries typically range between extremes; a minority possessing vast wealth, a larger group of middle-class, waged employees, and a majority of poor people, who often derive whatever income they gain from the informal sector. An attempt has been made in this document to focus as far as possible on this latter group, both as the people in greatest need, and as the majority of urban dwellers - although they are far from a homogeneous group. Many of the poor are relatively recent arrivals to urban living, whereas the urban elite have often been living in the town/city for generations. Commonly, people of roughly the same income level tend to live together in discrete areas of a town or city, but it should not be assumed that these areas are mutually exclusive. For example, in many Third World cities large numbers of poor people may be found living in affluent areas as residential labour. Within different parts of the Third World the pace at which urbanization is increasing, and the time at which the process began to accelerate, varies considerably. Broadly speaking, urbanization began earlier in Latin America, where already in $1990,72 \%$ of the entire population was urban dwellers. This compares with an overall $34 \%$ of the total population of Africa which was urbanized in 1990, and 33\% in Asia. Within each region of the Third World, urbanization rates also vary, although to a lesser extent in Latin America than elsewhere. In the former, urbanization is highest in South America (75\%), and lowest in the Caribbean (60\%), where some countries (such as Haiti and Saint Vincent) are still predominately rural. In Africa, the countries in the East have the lowest percentage of urban dwellers (22\%), while those in the Southern block have the highest (55\%). Asia's population figures are strongly influenced by China, which has an urbanization level of $33 \%$, but it is only in Western Asia that more than half (63\%) of the population lives in urban settlements. If current (1990-1995) annual rates of urbanization are compared, it may be seen that the process is most rapid in Africa (4.9\%), particularly in the Eastern part of the continent (6.4\%). It is also high in Asia (4.5\%), where China's current rate of urbanization is calculated to be $6.6 \%$. Urbanization in Latin America has already slowed to an annual rate of $2.6 \%$, after a peak rate in the 1950 s (when it also averaged a $4.5 \%$ annual growth of its urban population).

The housing need has thus been an issue of global concern as the housing provision still remains one of the intractable problems facing mankind (Konadu-Agyemang, Noonam, \& McCord, 1994). The most adversely affected in this regard are the urban poor, who constitute the majority in the developing countries of Africa and Asia wherein, according to a UN Report, consists of cities which now account for over 90 percent of the world's urban population growth (UN -Habitat, 2006).In developing countries where there is rapid urbanization, the problem of inadequate housing for the people, especially among the low-income group, constitutes one of the major challenges to economic development and the welfare of citizens. Existing studies have shown the rate at which urban growth are increasing in most African countries, and the major factors for these rapid increases, relate to large-scale migration into the urban centers for employment and wealth acquisition, natural increase of the population, and lopsided concentration of investments by both governments and private organizations (Ajala, 2005; Jiboye \& Omoniyi, 2010). Despite these rapid growths and population increases, evidence also revealed a rapid decrease in the addition of new housing stock, as well as poor state and inadequate urban housing infrastructures to support the increasing population (Aguda \& Ajala, 1998; Jiboye, 2009). The number of homeless people worldwide has grown steadily in recent years. In some Third World nations such as Nigeria, and South Africa, homelessness is rampant, with millions of children living and working on the streets. Homelessness has become a problem in the countries of China, India, Thailand, Indonesia, and the Philippines despite their growing prosperity, mainly due to migrant workers who have trouble finding permanent homes. For people in Russia, especially the youth, alcoholism and substance abuse is a major cause and reason for becoming and 
continuing to be homeless. According to United Nations, United Nations Centre for Human Settlements (UN-Habitat, 1995) wrote in its Global Report on Human Settlements in 1995: "Homelessness is a problem in the developing countries and developed countries. In London, for example, life expectancy among the homeless is more than 25 years lower than the national average. Poor urban housing conditions are a global problem, but conditions are worst in developing countries. (UN-Habitat, 1995) says that today 600 million people live in life and health threatening homes in Asia, Africa and Latin America. The threat of mass homelessness is greatest in those regions because that is where population is growing fastest. By 2015, the 10 largest cities in the world will be in Asia, Latin America and Africa. Nine of them will be in developing countries: Mumbai, India - 27.4 million; Lagos, Nigeria - 24.4; Shanghai, China - 23.4; Jakarta, Indonesia - 21.2; São Paulo, Brazil - 20.8; Karachi, Pakistan - 20.6; Beijing, China - 19.4; Dhaka, Bangladesh - 19; Mexico City, Mexico - 18.8. The only city in a developed country that will be in the top ten is Tokyo, Japan - 28.7 million. In 2008 (Wikipedia, the free Encyclopedia, 2010).

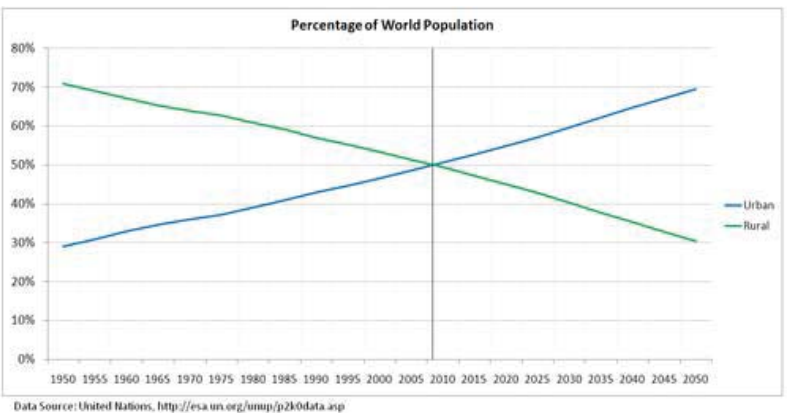

Source: Author's field survey, 2012

\section{Globalization of Homelessness}

Homelessness is a global problem. According to a 1996 United Nations report, 500 million people worldwide were homeless or residing in low-quality housing and unsanitary conditions in 1995. The number of homeless continues to rise, however, and quantifying this population is difficult. Homelessness, as defined by Wright (2007), "is the condition of people who lack regular legal access to adequate housing". Wikipedia, the free Encyclopedia (2010) defines it as "the condition and social category of people without a regular house or dwelling because they cannot afford, do not desire, or are otherwise unable to maintain regular, safe, and adequate housing, or lack, fixed, regular, and adequate night time residence". The term homelessness may also include people whose primary night time residence is in a homeless shelter, in an institution that provides a temporary residence for individuals intended to be institutionalized, or in a public or private place not designed for use as a regular sleeping accommodation for human beings. The actual legal definition varies from country to country, or among different entities or institutions in the same country or region.

The Housing Act 1988 defines a homeless person as somebody who has no reasonable accommodation to live in or lives in a hospital, institution or night shelter because of a lack of home. Different types of homelessness include visible homelessness - on the streets, sleeping rough, in shelters; hidden homelessness - in temporary, insecure, low quality or overcrowded housing with relatives or friends; living in bed and breakfast accommodation, and squatting.

Most homelessness rates are reported by service providers, and countries with the best-developed service systems will therefore report the highest number of homeless, a condition referred to as the service-systems paradox. However, homelessness gained national attention in the early 1980s. While some people thought the growth in the homeless population was a result of the recession that occurred during this period, the problem has not gone away. It is estimated that two million people per year are homeless in the United States. A report issued by the Urban Institute in 2000 stated that 2.3 million adults and children in the developing countries are likely to experience homelessness at least once in a year's way to get at the root of the problem is to understand the causes of homelessness.

Rehman and Gahagan (2003) cited in Jiboye, (20011) in their report on Harm Reduction in Canada, also defined homelessness as "the lack of a safe place where individuals and families can grow and contribute to the 'quality of life' in their community". The "homeless", as defined by the United States Federal Code 42 (2006), "is an individual who lacks a fixed, regular, and adequate night time residence". The United States Department of Housing and Urban Development 
(2009) defines a "chronically homeless" 141 person as "an unaccompanied homeless individual with a disabling condition who has either been continuously homeless for a year or more, or has had at least four episodes of homelessness in the past three years" The issue of homelessness and lack of access to decent housing have, over time, attracted global concern. Since early 1980s and 1990s, developed countries, such as the U.S and Canada have recognized this issue as a significant social problem, plaguing both the people and national development; however, concerted efforts have been directed at addressing it. A report by the National Law Center on Homelessness and Poverty in the U.S indicate that almost two million people are homeless on any given night in America (Almanac of Policy Issues, 2010). In another report, the National Coalition for the Homeless (2009) noted that homelessness constitutes a devastating experience for families. It disrupts virtually every aspect of family life, damaging the physical and emotional health of family members, interfering with children's education and development, and frequently resulting in the separation of family members. Montreal, (1987) defines a person with no fixed address, stable, safe and healthy housing for the next 60 days, an extremely low income, adversely discriminated against in access to services, with problems of mental health, alcohol and drug abuse or social disorganization, and not a member of any stable group. Worldwide, homelessness is caused by a breakdown in traditional family support systems, continued urbanization, the effects of structural adjustment programs, civil wars, and natural disasters.

\subsection{Types of homelessness}

Listed below are the six main types of homelessness identified since 1984.

Short-Term Homelessness: (usually within 30 days) Long-Term Homelessness: (sometimes up to 120 days.). Permanently Supported Homelessness: lacks both relational \& inner resources due to mental or physical disability. Near Homelessness, Self-Induced Homelessness: Self-induced homeless persons reject their relational resources by refusing to cooperate or submit to any form of authority. Environmentally Dysfunctional Homelessness: often as a result of the toxic environment in which they were exposed. (Inner City Mission, 2009). One of the most common ways of categorizing the homeless is to divide the total population into three subgroups. The three subgroups are: The chronically homeless: Includes people who live on the periphery of society. The cyclically homeless: Includes individuals who have lost their dwelling as a result of some change in their situation, such as loss of a job. The temporarily homeless: Includes those who are without accommodation for a relatively short period. (Lyne, 1999).

\subsubsection{Causes and Consequences of Homelessness}

Homelessness is a very complex issue that affects the community from an economic and a social perspective. In many parts of the world, several reasons have been provided to explain the dramatic increase in the number of homeless people. The root causes of homelessness include at least one of the following: The rising costs of housing, Poverty and the lack of affordable housing: current levels of housing costs, coupled with low-wage jobs, Divorce, domestic violence and lack of family support, Broken relationships, Chronic health problems or physical disabilities, Sudden job loss due to injury or illness, Mental illness, Drug, alcohol and gambling addictions, Natural disasters. (Community Housing Plan, 2002). Studies have shown that poverty, lack of affordable housing, and domestic violence are the principal causes of family homelessness in America and Canada; and this has increased overtime (Rehman \& Gahagan, 2003; National Coalition for the Homeless, 2009). At the same time, a lack of affordable housing has resulted in an inability to obtain adequate, appropriate, and affordable housing. In many cases people are being required to spend larger amounts of money to obtain substandard housing or are not able to acquire accommodation due to unemployment rates, family violence and abuse, and the cancellation of government support (Rehman \& Gahagan, 2003). However, tackling the problems of homelessness is a complex business and normally requires support from public bodies, friends and family, combined with a lot of hard work from the individual or family. Public support might include intervention, advice, counseling, training or provision of alternative accommodation by a local authority where appropriate

\subsection{The Concept of Sustainable Housing Development}

The general goal of sustainable development is to meet the essential needs of the world's poor while ensuring that future generations have an adequate resources base to meet theirs. It is thus geared towards meeting the needs of the present generation without compromising the ability of future ones to meet their own needs (WCED, 1987 ; Olotuah and Bobadoye, 2009). 
The World Commission on Environment and Development in their report defines the concept of sustainable housing development as "development which meets the housing needs of the present without compromising the ability of future generations to meet their own needs" (World Commission on Environment and Development, 1987). Sustainable housing development is the gradual, continual and replicable process of meeting the housing needs of the populace, the vast majority of who are poor and are incapable of providing adequately for themselves (Olotuah and Bobadoye, 2009). Sustainable housing development ensures housing strategies that are stable and are not subject to vagaries in the political circumstances of the country. Sustainable housing provision requires proper definition of housing needs, and the participation of the end users to ensure their satisfaction. (Olotuah and Bobadoye, 2009).

The concept of sustainable housing development has been one of the most discussed and adopted global topical issues most especially in Nigeria, the concept is a shift from a mere sustained growth of a society, to the level whereby such growth does not jeopardize the need of the future generation (Jiboye, 20011) Agenda 21 of the Earth Summit focused on the sustainability of cities at two levels: first, at the global level, it involves a range of issues concerning long term sustainability of the earth; secondly, at the local level, which involved the possibility that urban life may be undermined from within because of congestion, pollution, waste generation, and their accompanying social and economic consequences. Eight relevant programs specifically aimed at addressing the shelter needs of the people were outlined within the agenda (Oduwaye, 2009).

Sustainable housing provision is thus contingent on such underlying factors as policy formulation and decision making, policy execution and monitoring, and social acceptability and economic feasibility. These factors must take into cognizance the bottom-up participatory approach in housing provision involving genuine local participation by people at the grassroots level (Olotuah \& Aiyetan, 2006).

Furthermore, Sustainable housing development is premised on the articulation and incorporation of environmental and human needs in the pursuit of economic growth and development objectives. It, however, has human, socioeconomic, and physical development dimensions (Oduwaye, 2009). Also National Affordable Housing Agency of Britain (2006) describes the concept as that which "ensures a better quality life for everyone, now and for generations to come". In a broader form, it is the process of building our communities so that we can live comfortably without consuming all of our resources.

Achieving sustainability in housing provision requires major societal changes, restructuring of institutions and management approaches. The appropriate political will based on the conviction of the responsibility of government to its citizens, and the need to create humane and decent environment for dignified living. In order to realize sustainable housing provision the housing needs of the Nigerian population have to be put into proper focus, and a coordinated programme to achieve this should be thoroughly worked out. (Olotuah and Bobadoye, 2009). In conclusion, Ibadan as the largest city in Africa, housing should be made sustainable to the homeless people in Ibadan to solve the problem of homelessness as one of the measure taken to alleviate the problems of housing in the developing world.

\section{Study Area}

The city of Ibadan is located approximately on longitude $3^{0} 5^{1}$ East of the Greenwich Meridian and latitude $7023^{1}$ North of the Equator at a distance some 145kilometres worth east of Lagos. Ibadan is directly connected to many towns in Nigeria, as its rural hinterland by a system of roads, railways and air routes. The physical setting of the city consists of ridges of hills that run approximately in northwest - southeast direction. The largest of these ridges lies in the central part of the city and contains such peaks as Mapo, Mokola and Aremo. These hills range in elevation from 160 to 275 metres above sea level and thus affords the visitor a panoramic view of the city. The city's total area is 1,190 sq mi $\left(3,080 \mathrm{~km}^{2}\right)$. The city is naturally drained by four rivers with many tributaries: Ona River in the North and West; Ogbere River towards the East; Ogunpa River flowing through the city and Kudeti River in the Central part of the metropolis. Ogunpa River, a third-order stream with a channel length of $12.76 \mathrm{~km}$ and a catchment area of $54.92 \mathrm{~km}^{2}$. The most probable date of the founding of Ibadan is 1829, when the abandoned settlement of Ibadan was preoccupied by the allied forces of ljebu, Ife and Oyo; hence, it came to be regarded as 'a war encampment' of the town of warriors. Ibadan has served as the administrative centre for the whole of Southern Nigeria $(1946$ - 1951) and as the capital of the Western Region (1951 1967). After this period, the city's region started to shrink, to cover just the Western Region (1963 - 1967); Western State and old Oyo State (1976 - 1991), before the creation of Osun State, (1976-1991).It has been the capital of present Oyo State since 1991. The Political status of the city has influenced other aspect of its development. One of which is the reminiscence of colonial administration. The Government Secretariat at Agodi and the Government Reservation Areas (GRAs) A at Agodi, Jericho and Onikere are relice of that era. The grid pattern of the residential layout of Oke - Bola and 
Oke - Ado is also associated with its activities. Ibadan also has many recreational and tourist centres of attraction: Liberty Stadium and Lekan Salami stadium, the PoloClub, the botanical Garden, the Zoo and the Trans wonderland Amusement Park. The cultural Centre, Mapo Hall, Ido, Centaph and the Bowers Tower are other tourist centres of historical culture value. Ibadan has an airport and is served by the Ibadan Railway Station on the main railway line from Lagos to Kano. The bad economic situation in the country has adversely affected the quality of public transportation. It is therefore advisable to arrange transportation before traveling to Ibadan. The city is respectively well linked by road, rail and air both domestic and internationally. The intra city road network provide the major links with its different parts. Recently, the Ibadan - Lagos Express way the Ring road network were built to ease traffic congestion in the city. Ibadan presents fascinating landscape of tradition and modern features Prominent in its old, indigenous core area are the I ba's marked (Oja'ba) and the king's place. Force Mopo Hill, one can easily see the sea of rusted brown roofs and buildings in places like Agugu, Ayeye, Idi Arere, Odinjo, Gege and Foko, to mention but a few. These are interspersed by neighborhoods, of new and modern buildings, which are linked and crisscrossed by winding roads. Other places are at the periphery of the core centre. The include Odo Ona, Apata Ganga and Owode Estate, to the west, to the south are Challenge, Molate and Felele areas. Those to the north are Oorogun, Ojoo, Sasa etc, while to the north - east are Bodija, Akobo, Monatan and Isebo. The outward of the city is in all direction of the seven main riges that dominate the city of Landform. The sprawl has also been in the of the railway that runs in a southwest-northwest direction of the city of the road networks, which link the city with almost all the cardinal points of the country. Some of the contributive factors to its spread are: the Ibadan - Lagos and the Ring Road - Adeoye Express ways, the establishment of institutional area housing and industrial estates. Examples of the last three named factors are the University of Ibadan, Polytechnic, Bodija Odogbo Army Barracksm Jericho, Owode and Felele Housing Estates, NNPC Oil Storage Deport, Apata and Oluyole and Lagelu Housing and Industrial Estate. Other newly developing area of the city includes Eleyele, Challenge, Gbanda, Ikolaba, Akobo, Monatan, Adegbayi, Olodo and Olomi. Ibadan is an exception educational centre. It has numerous primary and post primary institutions, such as the University of Ibadan, the first University in the country, and world renowned. The Polytechnic and several research institutes, such as the Nigeria Horticulture Research (NISER) and the Institute of Agriclture, Research Training (IAR \& T). Also, there is a private University, the lead City University, Ibadan, and a host of private secondary institutions.

\section{Research Methodology}

Ibadan City Council basically consist of six District Councils for the city namely: Ibadan North District Council with the headquarters at Moniya, Ibadan East District Council with the headquarters at lyana-Offa, Ibadan South-East District Council with the headquarters at Akanran, Ibadan South District Council with the headquarters at Olode, Ibadan SouthWest District Council with the headquarters at Idi-Ayunre, Ibadan West District Council with the headquarters at Ido. The six headquarters of this district ( Moniya, Iyana-offa, Akanran, Olode, Idi-Ayunre and Ido) represent the sampling areas of the research. The areas identified in each of this headquarters include the market place, motor parks, residential neighborhoods, as well as vehicular and pedestrian bridge locations. In order to determine the homeless rate, effect, causes a quantitative data collection technique, namely 'survey method' was used. The research instrument called 'Structured questionnaire' on homeless was designed to covered relevant information on the socio-economic and housing characteristics of the respondents who have been affected by the problem of inadequate housing in Ibadan. The questionnaire was designed to covered paramount issues such as: access to shelter, Length of being homeless, Reason for homelessness, effects of being homeless, Solution to homelessness, such respondents were mostly found in commercial areas and residential hideouts of the community. However, for equal representation of the entire area, eighty four (84) copies of the questionnaire were administered randomly to respondents in each of the selected locations within the area. Consequently, a total of 504 questionnaires were administered and a total no of 500 questionnaires were retuned back from the respondents. The results of the information given by the respondents of various socio-economic characteristics were analyzed using statistical package for social sciences.

\section{Findings and Discussion}

The table below shows the distribution by the socio-economic characteristics of homeless people in Ibadan indicating that more than half of the respondents about $69.6 \%$ are male students and about $30.4 \%$ are female respondents. This report have shown that majority of the homeless people at Ibadan (41.8\%) are between the ages of 21-25 years, While $31.6 \%$.of the people sample are between the ages of $15-20$ years and $26.6 \%$ are between the ages of $26-30$ years. The 
research identified that, the major occupation of the homeless people at the six areas sampled at Ibadan are, Bus conductor, Night Guard, Trader, Butchering, alms begging and Touting. The report confirmed that, Bus conductors are the most homeless people at Ibadan which amount to about $30 \%$ of the respondents while $17 \%$ of the homeless people at Ibadan are butchering and $16 \%$ of the homeless people are Petty Trader also 13\%, 13.6\% and 10.4\% are Alms begging, Touting and Night Guard respectively. The table also shows that, $40 \%$ of the respondents are in the areas sampled are Yoruba, while 32\% of them are Igbo, $24 \%$ are Hausa while $4 \%$. Of the respondents emerged from other tribes. Based on the marital status of the respondents, of the,

the distribution of the table above shows that, a greater percentage of the homeless people are single which amounts to $48 \%$ and $30.4 \%$ of the respondents are Married while $10.2 \%$ only are divorced, also $8.4 \%, 3.0 \%$, are Widowed and separated respectively. Distribution by income also shows that $60.6 \%$ which is the majority of the respondents earn less than $\# 2,000$ per month, about $20.2 \%$ of the respondents earn between $\# 2,000$ and $\# 5,000$ per month and about $19.0 \%$ of the respondents earn between $\# 5000$ and $\# 7,000$ while just $0.2 \%$ of the respondents earn $\# 7,000$ and above.

Table 1: Socio-Economic Characteristics of the Respondents

\begin{tabular}{|c|c|c|c|}
\hline \multicolumn{2}{|c|}{ Socio-Economic Characteristics } & $\begin{array}{c}\text { Frequency } \\
\text { No }\end{array}$ & $\begin{array}{c}\text { Percent } \\
\%\end{array}$ \\
\hline \multirow{3}{*}{ Sex } & Male & 348 & 69.6 \\
\hline & Female & 152 & 30.4 \\
\hline & Total & 500 & 100 \\
\hline \multirow{4}{*}{ Age } & $15-20$ & 158 & 31.6 \\
\hline & $21-25$ & 209 & 41.8 \\
\hline & $26-30$ & 133 & 26.6 \\
\hline & Total & 500 & 100 \\
\hline \multirow{7}{*}{ Occupation } & Bus conductor & 150 & 30.0 \\
\hline & Night guard & 52 & 10.4 \\
\hline & Petty trading & 80 & 16.0 \\
\hline & Butchering & 85 & 17 \\
\hline & Alms begging & 65 & 13 \\
\hline & Touting & 68 & 13.6 \\
\hline & Total & 500 & 100 \\
\hline \multirow{5}{*}{ Ethnicity } & Yoruba & 200 & 40 \\
\hline & Igbo & 160 & 32 \\
\hline & Hausa & 120 & 24 \\
\hline & others & 20 & 4.0 \\
\hline & Total & 500 & 100 \\
\hline \multirow{6}{*}{ Marital status } & Single & 240 & 48 \\
\hline & Married & 152 & 30.4 \\
\hline & Divorced & 51 & 10.2 \\
\hline & Widowed & 42 & 8.4 \\
\hline & Separated & 15 & 3.0 \\
\hline & Total & 500 & 100 \\
\hline \multirow{5}{*}{ Income in categories } & Less Than 2000 & 303 & 60.6 \\
\hline & $2000-5000$ & 101 & 20.2 \\
\hline & $5000-7000$ & 95 & 19.0 \\
\hline & Above 7000 & 1 & 0.2 \\
\hline & Total & 500 & 100 \\
\hline
\end{tabular}

Source: Authors Field Work (2011).

The table below shows the distribution by the respondents housing characteristics of homeless people in Ibadan indicating that more than half of the respondents which amounts to $70.8 \%$ have no good and comfortable shelter to live while $20.2 \%$ of the respondents can boost of good and comfortable Shelter to live. Similarly, these report shows that the highest numbers of homeless people at Ibadan (30\%) lived in uncompleted buildings, While 14\%, 13\%, 24\%, 10.6\%, 
7.8\% .of the homeless people sample lived in Abandoned Broken Vehicles, Street sheds hideout, under Bridges, Bus stop Garages, Inside public schools respectively. Also $24.2 \%$ of the respondents identified that, they have no good and comfortable shelter for about 15years to 25years, while $30 \%$ said they have no good and comfortable shelter for about 10years to 15years, $12 \%$ claimed that they have no good and comfortable shelter for about 5years, some also said they have no good and comfortable shelter for about 5years to 10years, Similarly, 5.0\% 4.4\% of the respondents claimed that they have no good and comfortable shelter for about 25-30 years and above respectively.39\% of the homeless people sampled were staying with their friends before while $10.6 \%$ were staying in their family house before they becomes homeless and $16.4 \%, 15 \%$ and $19 \%$ of the respondents were staying with their parents, relatives and in their matrimonial home respectively and majority of the respondents amount to $38.2 \%$ expressed their minds that if given an opportunity to resides in the residential area they would have prefer the core areas of the city. While $37.8 \%$ said they would have prefer Public Estates and $18 \%$ of the respondents said they would have prefer outskirt of the city while just $6.0 \%$ of the respondents said they would have prefer private estates.

Table 2: Determination of Respondents Housing Characteristics

\begin{tabular}{|c|c|c|c|}
\hline \multicolumn{2}{|c|}{ Respondents Housing Characteristics } & $\begin{array}{c}\text { Frequency } \\
\text { No }\end{array}$ & $\begin{array}{l}\text { Percent } \\
\%\end{array}$ \\
\hline \multirow{3}{*}{$\begin{array}{l}\text { Do you have good and comfortable } \\
\text { Shelter to live }\end{array}$} & Yes & 101 & 20.2 \\
\hline & No & 399 & 70.8 \\
\hline & Total & 500 & 100 \\
\hline \multirow{7}{*}{ If No, where do you shelter your self } & Uncompleted buildings & 150 & 30 \\
\hline & Abandoned broken Vehicle & 70 & 14 \\
\hline & Street Sheds hideouts & 68 & 13.6 \\
\hline & Under bridges & 120 & 24 \\
\hline & Bus stop Garage & 53 & 10.6 \\
\hline & Inside Public Schools & 39 & 7.8 \\
\hline & Total & 500 & 100 \\
\hline \multirow{7}{*}{ How long have you being homeless } & About Five Years & 61 & 12.2 \\
\hline & Between 5 and 10 years & 101 & 20.2 \\
\hline & Between 10 and 15 years & 150 & 30 \\
\hline & Between 15 and 25 years & 121 & 24.2 \\
\hline & Between 25 and 30 years & 45 & 5.0 \\
\hline & Above Thirty years & 22 & 4.4 \\
\hline & Total & 500 & 100 \\
\hline \multirow{6}{*}{$\begin{array}{c}\text { Where do you stay before you are } \\
\text { homeless }\end{array}$} & Staying with friends & 195 & 39 \\
\hline & Staying in family house & 53 & 10.6 \\
\hline & Staying with parents & 82 & 16.4 \\
\hline & Staying with relatives & 75 & 15 \\
\hline & In my matrimonial home & 95 & 19 \\
\hline & Total & 500 & 100 \\
\hline \multirow{5}{*}{$\begin{array}{l}\text { If given an opportunity to resides in } \\
\text { residential area, where would you } \\
\text { prefer to reside }\end{array}$} & In the core area of the city & 191 & 38.2 \\
\hline & Public Estate & 189 & 37.8 \\
\hline & Private Estate & 30 & 6.0 \\
\hline & Outskirt of the City & 90 & 18 \\
\hline & Total & 500 & 100 \\
\hline
\end{tabular}

Source: Authors Field Work (2011).

The table below shows the distribution by the causes, effects and solution to homelessness indicating that $36.4 \%$ of the respondents claimed that homelessness is caused by high cost of housing rent while $28.0 \%$ is caused by lack of good employment and 20.2\%, 10.4\% 4.0\%, 1.0\% claimed that homelessness is caused by Broken marriage, Mental illness, Natural Disaster and No particular reason respectively. $26 \%$ of the homeless people at Ibadan have rated Lack of Security as the most effects of being homeless in Ibadan while Limited access to education was rated to be the least effects of being homeless at Ibadan, also $14 \%$ rated poverty to be one of the effects of being homeless and $24.4 \%$ of the respondents rated lack of good health as one of the effects of being homeless. Social Neglect is also one of the effects 
rated by the respondents to be $24 \%$. From the table, Provision of more houses, Poverty reduction methods, Building materials price reduction, Availability of Land, Employment opportunity are some of the solutions to homelessness suggested by the sampled respondents.39.8\% of the respondents claimed that Provision of more houses either from the stake holders or from the government while $18.2 \%$ respondents stated that homelessness can be eradicated through Poverty reduction methods .It should also be noted that one of the major causes of homelessness is poverty in the developing nation is the issue of high rate of poverty. Employment opportunity has been identified as one of the method discovered to solve the problem of homelessness about 21.4\% respondents rated Employment opportunity as a solution to homelessness in Ibadan. Building materials price reduction which amounts to $9.4 \%$ has been rated the lowest method that could be adopted to solve the problem of homelessness in the developing world. Also availability of land rated $11.2 \%$ ware also suggested to be a solution to the problem of homelessness.

Table 3: Causes, Effect and Solutions to Homelessness

\begin{tabular}{|c|l|c|c|}
\hline \multicolumn{2}{|c|}{ Respondents Housing Characteristics } & $\begin{array}{c}\text { Frequency } \\
\text { No }\end{array}$ & $\begin{array}{c}\text { Percent } \\
\%\end{array}$ \\
\hline \multirow{4}{*}{ Reason for being homeless } & High cost of Housing rent & 182 & 36.4 \\
\cline { 2 - 4 } & Lack of good employment & 140 & 28.0 \\
\cline { 2 - 4 } & Broken Marriage & 101 & 20.2 \\
\cline { 2 - 4 } & Mental illness & 52 & 10.4 \\
\cline { 2 - 4 } & Natural Disasters & 20 & 4.0 \\
\cline { 2 - 4 } & No particular Reason & 5 & 1.0 \\
\cline { 2 - 4 } & Total & 500 & 100 \\
\hline \multirow{4}{*}{$\begin{array}{c}\text { What do you think is the major effect of being } \\
\text { homeless }\end{array}$} & Poverty & 70 & 14 \\
\cline { 2 - 4 } & Lack of Security & 130 & 26 \\
\cline { 2 - 4 } & Social Neglect & 120 & 24 \\
\cline { 2 - 4 } $\begin{array}{c}\text { In your opinion, what do you think } \\
\text { government can do eradicate homeless } \\
\text { problems }\end{array}$ & Lack of good health & 122 & 24.4 \\
\cline { 2 - 4 } & Limited access to education & 58 & 11.6 \\
\cline { 2 - 4 } & Total & 500 & 100 \\
\hline & Provision of more houses & 199 & 39.8 \\
\cline { 2 - 4 } & Poverty reduction methods & 91 & 18.2 \\
\cline { 2 - 4 } & Building materials price reduction & 47 & 9.4 \\
\cline { 2 - 4 } & Availability of Land & 56 & 11.2 \\
\cline { 2 - 4 } & Employment opportunity & 107 & 21.4 \\
\cline { 2 - 4 } & Total & 500 & 100 \\
\hline
\end{tabular}

Source: Authors Field Work (2011).

\section{Conclusion}

The study has discussed the essential connections between urbanization, environment and homelessness in the developing world, through the information sourced from literature review on urbanization and homelessness in particular as well as information relating to the environment. Majority of the respondents are male and their ages are between 1530 years of age. From the analysis, Bus conductors, petty traders and butchering are the major work of these homeless people while others engaged in touting and alms begging, also the highest percentage of those people who are homeless are from the Yoruba land, these is not a surprise because, Ibadan is situated at the southwestern Nigeria. The majority of this people are mot married, these is as a results of lack of sustainable/affordable housing for the respondents to protect their family because less than $\# 2,000$ is the income of the majority of these homeless people these money is not sufficient enough for them to get accommodation for the family. Out of (500) five hundred respondents sampled, (399) three hundred and ninety nine people have no comfortable shelter to live, the reports shows that, larger percentage of the these people lived in uncompleted buildings and under the bridges while others lived in the streets sheds hideouts, inside public schools, bus stop garage and abandoned broken vehicles, most of them has been living in their various shelters not less than five years. Because of high of high cost of housing rent, lack of good employment and broken marriage were rated the most reasons of being homeless in Ibadan, while others stated that mental illness and natural disasters. The results from the respondents sampled, shows that lack of security, poverty, social neglects, lack of good health and education were identified some of the effects of being homeless in Ibadan. The study revealed that increase 
in population (urbanization) courses high level of homelessness which eventually have effects on the environment, it has however, exposed the deplorable and pathetic situations of the homeless and urban poor in the developing world. It also shows that Lack of affordability of housing/housing support, insufficient incomes/poverty, unemployment and among other several is the causes of homelessness. Therefore, there is a need to make housing provision a major issue in the national development programs so as to improve the living conditions of the people in Ibadan. Government and developers has been called upon to by the respondents interviewed to solve the problem of homelessness through the provision of more affordable/sustainable houses, poverty reduction methods, and reduction in the cost of building materials, availability of land, employment opportunities.

\section{Reference}

ACHR, (2002) .Housing by People in Asia. Newsletter of the Asian Coalition for Housing Rights-Special Issue Community Funds. No14. Aguda, A.S. \& Ajala, O.A. (1998). Servicing Large and Medium-Sized Urban Centres. Ife Social Sciences Review, 15(1), 125.

Ajala, O.A. (2005). Environmental Impact of Urbanization: The challenges to Urban Governance in Nigeria. In Fadare W, Ajayi A, Amole D. \& Babalola B. (eds.), Proceedings of the Conference on, Globalization, Culture and the Nigerian

Akingbohungbe, D. O. and Akinluyi, M.L, (2012). Residents' Perception of off Campus students' Housing Performance in Ile-lfe, Nigeria. Journal of Environment and Earth Science, International Institute for Science, Technology \& Education. Vol 2, No 7,pp 69-76.

Ambrosio, E. et al. (1992). The Street Health Report: A Study of the Health Status and Barriers to Health Care of Homeless Women and Men in the City of Toronto. Toronto: Street Health.

American Public Health Association, (1997). Supporting a National Priority to Eliminate Homelessness. Policy paper 9718.

Cabannes, Yves (1997). From community development to housing finance: from Mutiroes to Casa Melhor in Fortaleza, Brazil. Environment \& Urbanization. Vol. 9 No. 1, April.

Institute of Medicine (1998). Homelessness, Health and Human Needs. Washington, DC: National Academy Press.

Jiboye, A.D (2011). Homelessness in Lagos Nigeria: Challenges To Sustainable Development. Journal of Sustainable Development in Africa. Vol. 13, No2.pp 138-154.

Jiboye, A.D. \& Omoniyi, S.S. (2010). Environmental Sustainability and urban growth in Nigeria. Proceedings of International Conference on, Engineering Research and Development, 1(2). Port-Harcourt, Nigeria.

Konadu-Agyemang, K., Noonam, J.M., \& McCord, D. (1994). Social Housing and Social Integration in the Durham Region of Ontario, Canada. Ekistics, 366, 367, 145-155.

Merkle, Caspar (2003). Youth participation in El Alto, Bolivia. Environment \& Urbanization. Vol 15 No 1 April.

National Affordable Housing Association (2006). Sustainability; Policy Areas. Retrieved from: http://www.housingcorp.gov.uk, on March, 2009.

National Coalition for the Homeless (2009). Foreclosure to Homelessness: Why are people homeless? Washington, D.C. National Coalition for the Homeless.

Pleace, N., and Quilgors, D. (1996). Health and Homelessness in London. London: King's Fund.

Plumb, J. D. (1997). Homelessness: Care, Prevention and Public Policy. Annals of Internal Medicine 126(12):973-975.

Rehman, L. \& Gahagan, J. (2003). Everyone has a right to a house. A community needs assessment of harm reduction supports for the Hard to house. Halifax Regional Municipality Planning and Development Services. Retrieved from: http://www.halifax.ca /planning/Homelessness/Harm, on November, 2008.

Rojas, R.E. (2000). Bridging the Finance Gap in Housing and Infrastructure - Bolivia. Foundation Pro Habitat - Homeless International.

Menegat, R. (2002). Participatory democracy and sustainable development: integrated urban environmental management in Porto Alegre, Brazil. Environment \& Urbanization. Vol 14 No 2, October 2002.

UN-Habitat (2002) . Best Practice -Reintegration program for the Homeless to farming environment. Antananarivo Madagascar.

Fuentes, P. \& Reiko .N. (2002). Motivating municipal action for children: the Municipal Seal of Approval in Ceará, Brazil. Environment \& Urbanization. Vol 14 No 2.

Velasquez, L.S. (1998) Agenda 21; Form of joint environmental management in Manizales, Colombia. Environment \& Urbanization. Vol.10 No.2.

UN-Habitat (2002) - Best Practice - Urban and Environmental Rehabilitation of Sao Bernardo do Campo Watershed Brazil.

McLeod, R. (2002). Paucity and capacity within city financing. Paper produced as part of Homeless International's Bridging the Finance Gap in Housing and Infrastructure research project, Homeless International, Coventry.

UN-Habitat. (2006). Milestones in the evolution of human settlements policies: 1976-2006. State of the world cities. The MDGs and urban sustainability. 30 years of shaping the Habitat Agenda. UK: Earthscan.

United Nations Department of Public Information. (2008). Achieving the Millennium Development Goals in Africa. Recommendations of the MDG Steering Group. Retrieved from: http://www.mdgafrica.org.pdf, on March 2009. Wikipedia, the free Encyclopedia. (2010). Homelessness. Retrieved from: http://en.wikipedia.org/wiki/Homele-ssness on August, 2010. ess.

World Commission on Environment and Development (1987). Our Common Future. Oxford, New York: Oxford University Press

Wright, J.D. (2007). Homelessness, Washington. Microsoft Corporation. Retrieved from: Microsoft Encarta 2007, on August 2010. 
